\title{
Comparing milk microbial quality and hygiene between milk processed at home and milk processed by industries in Kicukiro district, Kigali City- Rwanda
}

\author{
Onuike Godwin Ugochukwu ${ }^{1 *}$, Jean Baptiste Niyibizi ${ }^{1,2}$
}

1. Mount Kenya university Rwanda, Medical Laboratory Sciences department

2. University of Global Health Equity, Rwanda, Basic Medical Sciences department

\section{Corresponding Author: Onuike Godwin Ugochukwu,uggochukwu680@gmail.com}

\begin{abstract}
Pasteurized milks are still causing food borne illness. Milk contamination can occur at any stage from its way from cow to our tables. Usually milk is pure and sterile when produced in udder of a healthy cow. Like humans, cow are reservoirs of bacteria which are harmless to humans and some cows can harbour few bacteria that are harmful to humans even though they are not harmful to the cow. Milk can be contaminated during or after milking. Also, cow feeds can be contaminated with mycotoxins such as aflatoxins produced by the fungi, Aspergillus flavus. Four types of aflatoxins are known which are; aflatoxin B1, B2, G1, G2. Cows consuming feeds contaminated with aflatoxin B1 leads to secretion in the milk of aflatoxin M1 and M2 causing aflatoxicosis. Microbial contamination of milk and dairy products is a universal problem and foodborne infections accounting for 20 million cases annually in the world have been identified as an important public health and economic problem in developed as well as developing nations. The main objective of this study was to determine milk microbial quality in Kicukiro district. The specific objectives are to identify bacteria pathogens in milk collected in Kicukiro district, to compare milk quality among sectors of Kicukiro district, to compare milk processed by industries and home-processed milk. The methodology employed in this research was cross-sectional and experimental as the study began with collection of raw data and went through laboratory analysis from July-August, 2018. The findings showed that $59.56 \%$ of the milk fell within Grade I - Grade III $(<200,000 \leq 2,000,000 \mathrm{cfu} / \mathrm{ml})$ and $40.42 \%$ of the milk samples were not within the acceptable limit of total count quality as per COMESA and EAS, non-lactobacilli and fungi were present in most samples as examined through microscope and no Staphylococcus aureus was present in any sample as examined by catalase and coagulase tests.
\end{abstract}


Keywords: Contamination, pathogens, bacteria, Escherichia coli, Staphylococcus aureus, hygiene, Shigella, salmonella, milk processing, foodborne infection, cfu.

\section{Background}

Milk is synthesized in specialized cells of the mammary gland and is virtually sterile when secreted into the alveoli of the udder (Tolle, 1980). Beyond this stage of milk production, microbial contamination can generally occur from three main sources, from within the udder, from the exterior of the udder and from the surface of milk handling and storage equipment (Bramleyet al., 1990). The health and hygiene of the cow, the environment in which the cow is housed and milked and the procedures used in cleaning and sanitizing the milk and storage equipment are all key in influencing the level of contamination of raw milk (Murphy et al., 2010). Equally important are the temperature and length of storage, which allow microbial contaminants to multiply and increase in numbers and all these factors will influence the total bacteria count (TBC) or standard plate count (SPC) (Murphy et al., 2010). Raw milk as it leaves the udder of healthy cows normally contains very low numbers of microorganisms and generally will contain less than 1,000 total bacteria per ml (Kurweil, 1973). In healthy cows, the teat cistern, teat canal and the teat apex may be colonized by a variety of microorganisms although microbial contamination from within the udder of healthy animals is not considered to contribute significantly to the total numbers of microorganisms in the bulk milk or to the potential increase in bacterial number during refrigerated storage (Murphy et al., 2010). Natural floras of the cow generally have little influence on Standard Plate Counts (SPCs) or Total Bacterial Count. While the healthy udder should contribute very little to the total bacterial count of bulk milk, a cow with mastitis has the potential to shed large numbers of microorganisms into the milk supply. The influence of mastitis on the total bacterial count of bulk milk depends on the strain of infecting microorganism(s), the stage of infection, and the percentage of the herd infected (Murphy et al., 2010). Infected cows have the potential to shed in excess of 107 bacteria per ml. If the milk from one cow with 107 bacteria per ml comprises $1 \%$ of the bulk tank milk, the total bulk tank count, disregarding other sources, would be 105 per ml (Bramleyet al., 1990). Mastitis organisms that most often influence the bulk milk count are Streptococcus spp., most notably S.agalactiaeand S. uberis (Bramleyetal., 1990;Gonzalez et al., 1986; Jefferey et al., 1987) although other mastitis pathogens have the potential to 
influence the bulk tank count as well. Staphylococcus aureus is not thought to be frequent contributor to total bulk tank although counts as high as $60,000 / \mathrm{ml}$ have been documented (Gonzalez et al., 1986). Detection of implied pathogens does not necessarily indicate that they originate from cows with mastitis. Potential environmental mastitis pathogens and/or similar organisms can occur in milk as a result of other contributing factors such as dirty cows, poor equipment cleaning and/or poor cooling. Other environmental mastitis organisms including coliform bacteria, streptococci and certain coagulase-negative staphylococcus spp., may influence bulk milk bacteria counts through other means (Zehneret al., 1986). S. agalactiae and $S$. aureus are not thought to grow significantly on soiled milking equipment or under conditions of marginal or poor cooling. Their presence in bulk tank milk is considered strong evidence that they originated from infected cows (Gonzalez et al., 1986; Bramleyet al., 1990).

\section{Methods}

\section{Research design}

The study design was cross-sectional and experimental to evaluate milk microbial quality in Kicukiro district of Kigali Rwanda. Milk samples were taken from systematically selected restaurants and shops that sell ready to drink milk in all sectors of Kicukiro district and were analyzed in Mount Kenya University Laboratory through culturing, staining and biochemical tests to determine possible species or strain of bacteria or fungi that might have contaminated any milk.

\section{Sample collection}

There was primary data and sample collections through personal interviews using well-structured questionnaires and with use of clean sterile containers respectively.

\section{Sample size}

The sample size was 50 in other to represent the whole kicukiro district. 5 samples were collected from each of the 10 sectors of Kicukiro district.

\section{Sample analysis}

Samples were analyzed in Mount Kenya University Laboratory through culturing, staining and biochemical tests to determine possible species or strain of bacteria or fungi that might have contaminated any milk. 


\section{Data analysis}

The result of the culture and data from the questionnaires were analyzed using excel and SPSS software

\section{Results}

\subsection{Bacteriological analysis}

\subsubsection{Bacterial plating (culture)}

For each milk sample tenfold, serial dilution $\left(10^{-1}\right.$ to $\left.10^{-6}\right)$ were made in sterilised test tubes with distilled water. One millilitre each of $10^{-4}$ was used for Total Bacterial count. Twenty millilitres of Nutrient agar and the diluted milk sample were mixed thoroughly. Plates were allowed to cool and solidify then they were incubated in an inverted position at $37^{\circ} \mathrm{C}$. The incubation time for Total Bacterial Count was 48hours.

\subsubsection{Total Bacterial Count}

Total colony/ bacterial count was performed with the colony counter. In Gahanga, 4/5 (80\%) had counts equal or less than 2,000,000 colony forming units(cfu) per ml, in Gatenga also2/5 (40\%) had counts equal or less than 2,000,000 colony forming units(cfu) per ml, in Gikondo 1/5 (10\%) had counts equal or less than 2,000,000 colony forming units(cfu) per ml,inKagarama, only two samples were able to get and 0/2 (0\%) of the samples had counts equal or less than 2,000,000 colony forming units(cfu) per $\mathrm{ml}$, in Kanombe, $4 / 5(80 \%)$ had counts equal or less than 2,000,000 colony forming units(cfu) per ml, in KIcukiro, $2 / 5(40 \%)$ had counts equal or less than 2,000,000 colony forming units(cfu) per ml, in Kigarama, 4/5 (80\%) had counts equal or less than 2,000,000 colony forming units(cfu) per ml, in Masaka, 4/5 (80\%) had counts equal or less than 2,000,000 colony forming units(cfu) per ml, in Niboye, $3 / 5(60 \%)$ had counts equal or less than 2,000,000 colony forming units(cfu) per ml, in Nyarugunga, 4/5 (80\%) had counts equal or less than 2,000,000 colony forming units(cfu) per ml. In total, the district had $\mathbf{8}(\mathbf{1 7 . 0 2 \%})$ of the total sample that lie in grade I i.e. $<2,00,000\left(2.0 \times 10^{5}\right) \mathbf{c f u} / \mathbf{m l}, \mathbf{1 1}(23.40 \%)$ of the total sample 
that lie in grade II i.e. $<2,00,000-1,000,000\left(2.0 \times 10^{5}-1.0 \times 10^{6}\right) \mathbf{c f u} / \mathbf{m l}, \quad 9(19.14 \%)$ of the total sample that lie in grade III i.e. $<\mathbf{1 , 0 0 0 , 0 0 0}-\mathbf{2 , 0 0 0 , 0 0 0}\left(1.0 \times 10^{6}-2.0 \times 10^{6}\right) \mathbf{c f u} / \mathbf{m l a n d}^{-}$ $19(40.42 \%)$ of the total samples greater than 2,000,000 (2.0x10 $) \mathbf{~ c f u / m l . ~ ( T a b l e ~ 3 . 1 ) ~}$

21 milk sellers buy fermented milk from industry while 26 milk sellers ferment their milk locally at home. From the industrial fermented milk sellers, $11(52.4 \%)$ had less than 2,000,000 cfu/ml and $10(47.6 \%)$ had greater than 2,000,000 cfu/ml. From the home fermented milk sellers, $17(65.4 \%)$ had less than 2,000,000 cfu/ml and $9(34.6 \%)$ had greater than 2,000,000 cfu/ml. (Table 3.2)

Table 3.1: Total count for bacteria, yeasts and moulds in samples from the 10 sectors of kicukiro

\begin{tabular}{|c|c|c|c|c|c|}
\hline SECTORS & $\begin{array}{l}\text { No. of } \\
\text { samples } \\
\text { analysed }\end{array}$ & $\begin{array}{l}\text { Grade I } \\
<200,000 \\
\text { cfu/ml }\end{array}$ & $\begin{array}{l}\text { Grade II } \\
>200,000- \\
1,000,000 \\
\text { cfu/ml }\end{array}$ & $\begin{array}{l}\text { Grade III } \\
>1,000,000- \\
2,000,000 \\
\text { cfu/ml }\end{array}$ & $\begin{array}{l}>2,000,000 \\
\mathrm{cfu} / \mathrm{ml}\end{array}$ \\
\hline Gahanga & 5 & $2(40 \%)$ & $0(0 \%)$ & $2(40 \%)$ & $1(20 \%)$ \\
\hline Gatenga & 5 & $0(0 \% 0$ & $2(40 \%)$ & $0(0 \%)$ & $3(60 \%)$ \\
\hline Gikondo & 5 & $0(0 \%)$ & $1(20 \%)$ & $0(0 \%)$ & $4(80 \%)$ \\
\hline Kagarama & 2 & $\mathbf{0}(\mathbf{0 \%})$ & $0(0 \%)$ & $0(\mathbf{0} \%)$ & $2(100 \%)$ \\
\hline Kanombe & 5 & $0(0 \%)$ & $2(40 \%)$ & $2(40 \%)$ & $1(20 \%)$ \\
\hline Kicukiro & 5 & $0(0 \%)$ & $1(20 \%)$ & $1(20 \%)$ & $3(60 \%)$ \\
\hline Kigarama & 5 & $2(40 \%)$ & $2(40 \%)$ & $0(0 \%)$ & $1(20 \%)$ \\
\hline Masaka & 5 & $3(60 \%)$ & $0(0 \%)$ & $1(20 \%)$ & $1(20 \%)$ \\
\hline Niboye & 5 & $1(20 \%)$ & $0(0 \%)$ & $2(40 \%)$ & $2(40 \%)$ \\
\hline Nyarugunga & 5 & $0(0 \%)$ & $3(60 \%)$ & $1(20 \%)$ & $1(20 \%)$ \\
\hline TOTAL & 47 & $8(17.02 \%)$ & $11(23.40 \%)$ & $9(19.14 \%)$ & $19(40.42 \%)$ \\
\hline
\end{tabular}

Table 3.1 shows that masaka sector has the best milk than other sectors as $60 \%$ of the milk samples from masaka fell within Grade I, 20\% in Grade II and 20\% in Grade III, while kagarama has worst 
milk as $100 \%$ of the only 2 sample fell out of standard (i.e. not within grade I - III) followed by Gikondo with $80 \%$ out of standard, then both Gatenga and Kicukiro with $60 \%$ out of standard.

Table 3.2: comparison between industrially and home fermented milk

\begin{tabular}{|l|l|l|l|}
\hline $\begin{array}{l}\text { Method of } \\
\text { fermentation }\end{array}$ & $\begin{array}{l}\text { No of } \\
\text { samples }\end{array}$ & $\begin{array}{l}<\mathbf{2 , 0 0 0 , 0 0 0} \\
\text { cfu/ml }\end{array}$ & $\begin{array}{l}\mathbf{> 2 , 0 0 0 , 0 0 0} \\
\text { cfu/ml }\end{array}$ \\
\hline $\begin{array}{l}\text { Industrially } \\
\text { fermented }\end{array}$ & 21 & $11(52.4 \%)$ & $10(47.6 \%)$ \\
\hline $\begin{array}{l}\text { Locally/home } \\
\text { fermented }\end{array}$ & 26 & $17(65.4 \%)$ & $9(34.6 \%)$ \\
\hline
\end{tabular}

Table 3.2 shows that both industrially and home fermented milk have greater percentage that fell within the standard $(<2,000,000 \mathrm{cfu} / \mathbf{m l})$.

\subsubsection{Gram staining.}

Milk samples were stained after incubation and colony count

Table 3.3: show different kinds of organisms (bacteria and fungi) seen with microscope after Gram staining.

\begin{tabular}{|c|c|c|}
\hline Sectors & Media used & Type of organisms seen \\
\hline \multirow[t]{2}{*}{ Gahanga } & Nutrient Agar & $\begin{array}{l}\text { Gram -ve bacilli, gram -ve coccobacilli, gram -ve } \\
\text { diplobacilli, gram -ve filaments, gram +ve staph, gram } \\
\text {-ve spore bearing filaments }\end{array}$ \\
\hline & Macconkey Agar & Gram -ve bacilli, gram +ve coccobacilli (bipolar stain), \\
\hline \multirow[t]{2}{*}{ Gatenga } & Nutrient Agar & $\begin{array}{l}\text { Gram -ve bacilli, Gram -ve coccobacilli, gram } \\
\text { +vesteptobacilli\& filaments, gram +ve staph, gram +ve } \\
\text { cocci \& diplococci, filaments with spores }\end{array}$ \\
\hline & Macconkey Agar & Gram -ve bacilli, gram -ve filaments \\
\hline \multirow[t]{2}{*}{ Gikondo } & Nutrient Agar & $\begin{array}{l}\text { Gram +ve streptococci, gram +vediploocci, gram -ve } \\
\text { coccobacilli, gram -ve bacilli, gram +ve bacilli, gram } \\
\text { +ve cocci, gram +ve staph, Gram -ve coccobacilli } \\
\text { (bipolar stain), Gram -ve staph, gram +ve streptococci }\end{array}$ \\
\hline & Macconkey Agar & gram -ve bacilli. \\
\hline Kagarama & Nutrient Agar & Gram -ve coccobacilli, Gram -ve bacilli \\
\hline
\end{tabular}




\begin{tabular}{|l|l|l|}
\hline & Macconkey Agar & Gram -ve coccobacilli, Gram -ve bacilli \\
\hline Kanombe & Nutrient Agar & $\begin{array}{l}\text { Gram +ve bacilli, Gram +vecocobacilli, Gram -ve } \\
\text { coccobacilli, Gram +ve bacilli, Gram -ve coccobacilli, } \\
\text { Gram -ve bacilli }\end{array}$ \\
\cline { 2 - 3 } & Macconkey Agar & No growth \\
\hline Kigarama & Nutrient Agar & $\begin{array}{l}\text { Gram -ve coccobacilli, Gram -ve staph, Gram +ve } \\
\text { streptococci, Gram +ve cocci, Gram +ve diplococci, } \\
\text { Gram +ve, staph, Gram +ve filaments }\end{array}$ \\
\cline { 2 - 4 } & Macconkey Agar & Gram -ve coccobacilli, gram -ve bacilli \\
\cline { 2 - 4 } & Macconkey Agar & $\begin{array}{l}\text { gram -ve bacilli, gram +ve coccobacilli, gram +ve } \\
\text { bacilli, gram +ve cocci }\end{array}$ \\
\hline Masaka & Nutrient Agar & $\begin{array}{l}\text { Gram -ve coccobacilli, gram +ve filaments, gram -ve } \\
\text { filaments, gram +ve bacilli, gram -ve bacilli, gram +ve } \\
\text { streptobacilli }\end{array}$ \\
\cline { 2 - 4 } & Macconkey Agar & No growth \\
\hline Niboye & Nutrient Agar & $\begin{array}{l}\text { Gram -ve coccobacilli, gram +ve cocci, gram +ve } \\
\text { diplococci, Gram -ve coccobacilli, }\end{array}$ \\
\cline { 2 - 4 } & Macconkey Agar & $\begin{array}{l}\text { Gram -ve coccobacilli, Gram -ve bacilli, Gram -ve } \\
\text { coccobacilli, }\end{array}$ \\
\hline Nyarugunga & Nutrient Agar & $\begin{array}{l}\text { Gram +ve rods(bacilli), Gram -ve bacilli, Gram +ve } \\
\text { bacilli, gram +ve coccobacilli, gram +ve } \\
\text { filaments(fungi), Gram -ve filaments. }\end{array}$ \\
\cline { 2 - 4 } & $\begin{array}{l}\text { Gram + streptococci, Gram -ve bacilli, Gram -ve } \\
\text { filaments, }\end{array}$ \\
\hline
\end{tabular}

From table 3.3, it shows that non-lactobacilli and fungi were found in the milk samples of kicukiro district.

Figures 3.1: shows some of the pictures captured with the microscope (optika vision) 


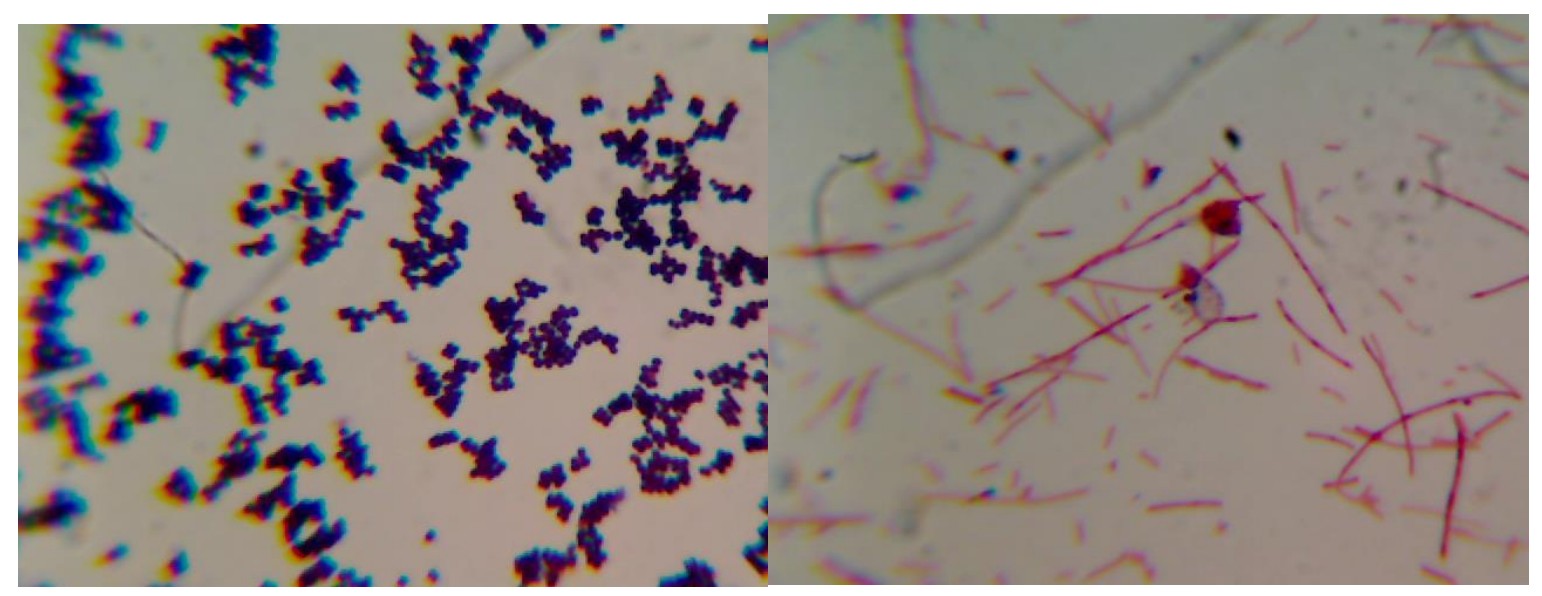

Gram +ve staph, Gram -ve bacilli and Gram -ve fungi with spores isolated from milk sample in Gahanga sector

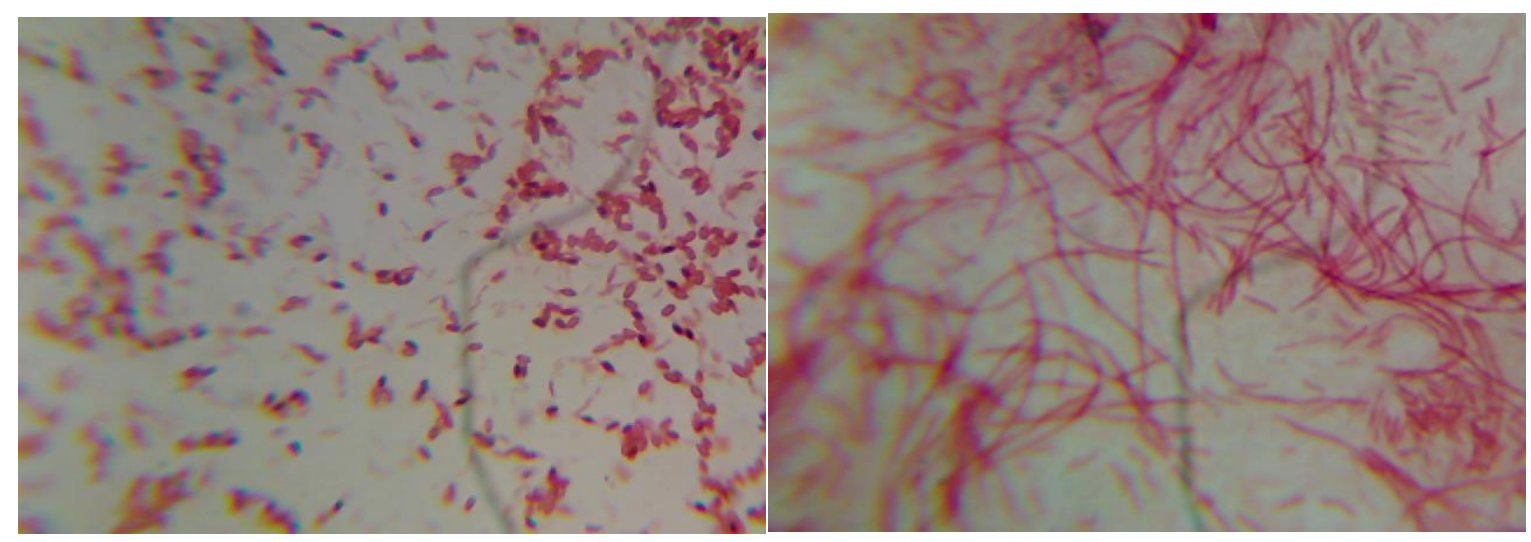

Gram -ve bacilli \& coccobacilli and Gram -ve bacilli \& filamentous bacteria in nutrient agar and macconkey gar respectively isolated from milk samples in gatenga sector.

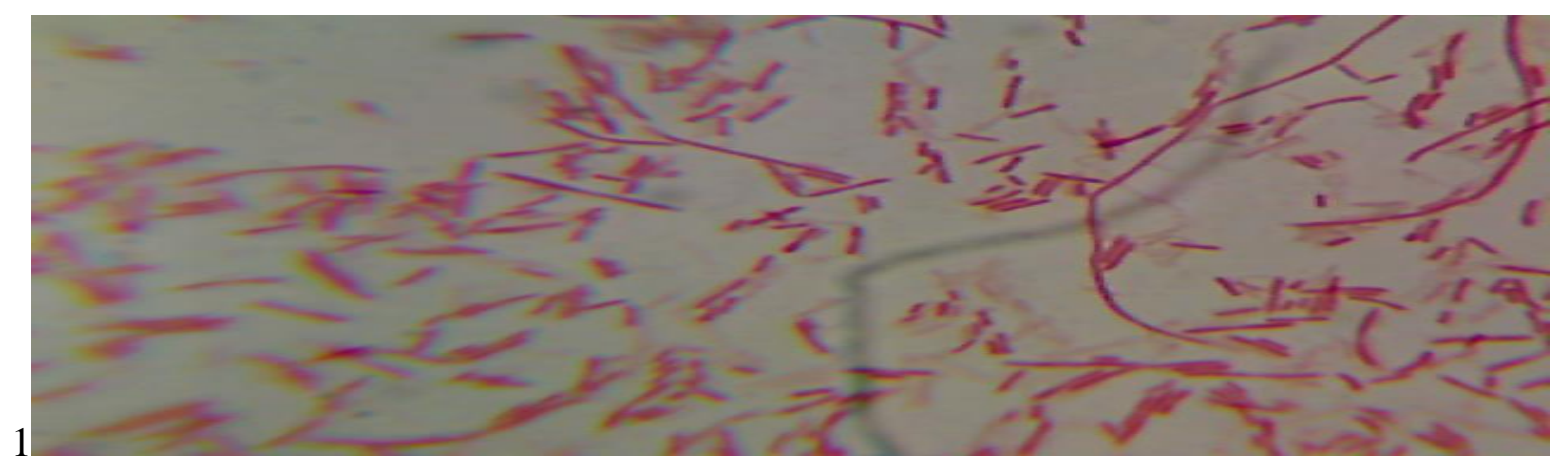



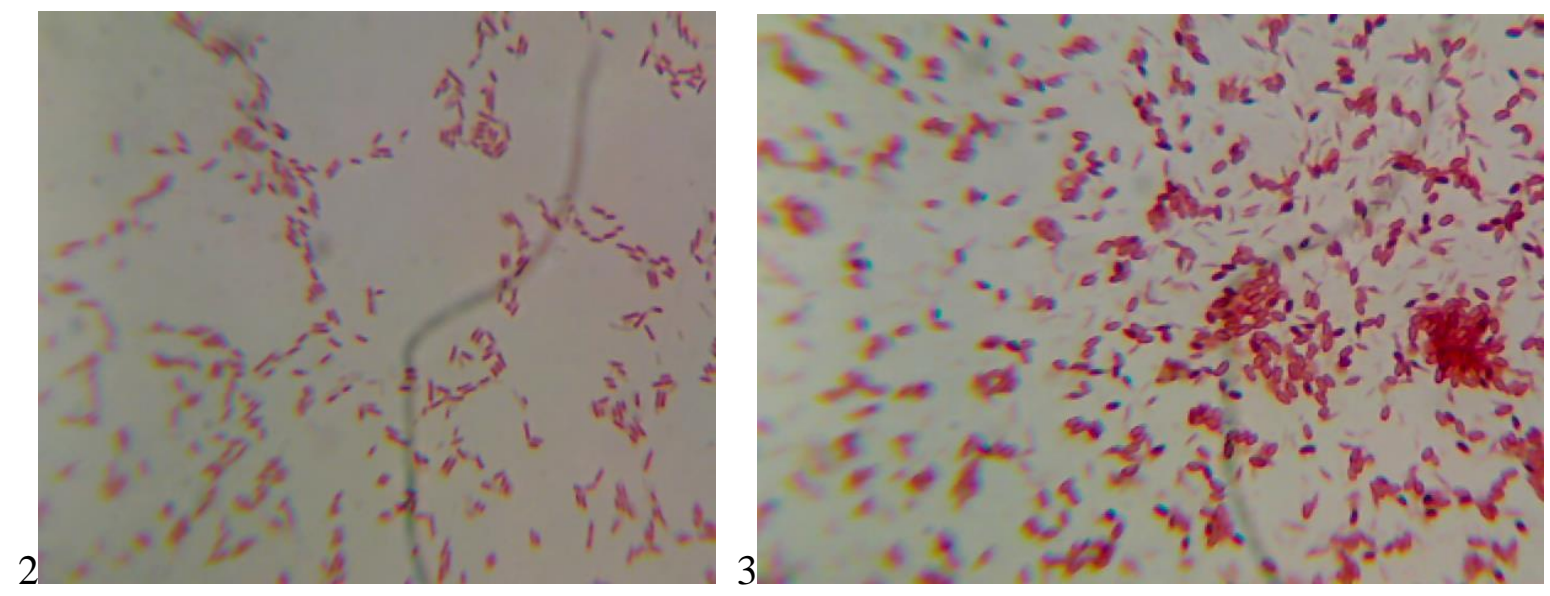

Gram -ve bacilli \& filamentous bacteria (1), Gram -ve bacilli (2) and Gram -ve bacilli \&coccobacilli (3) in macconkey (1\&2) and gar nutrient (3) agar respectively isolated from milk samples in Gikondo sector.

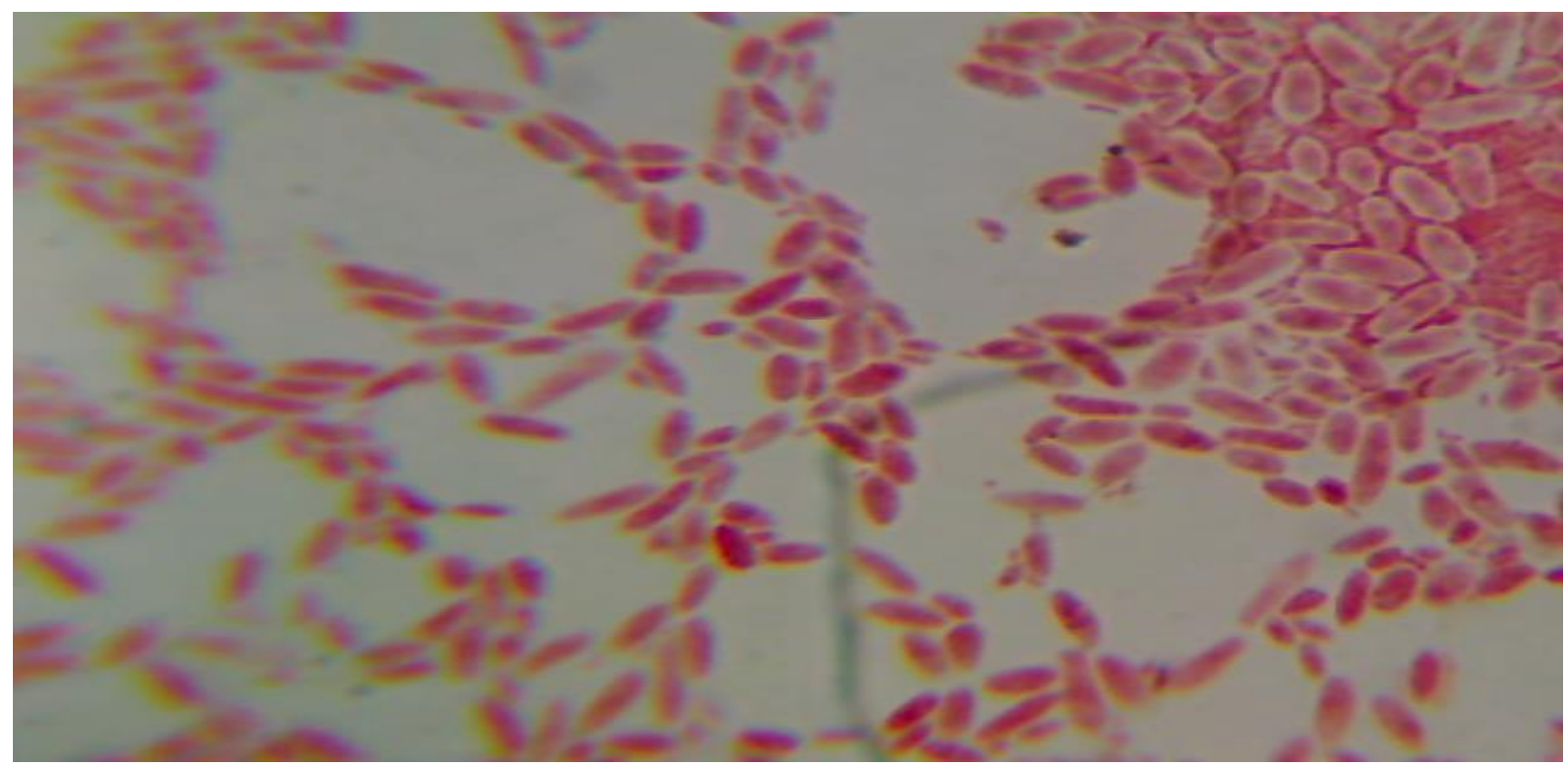

Gram -vecocobacilli isolated from milk sample in Kagarama sector 


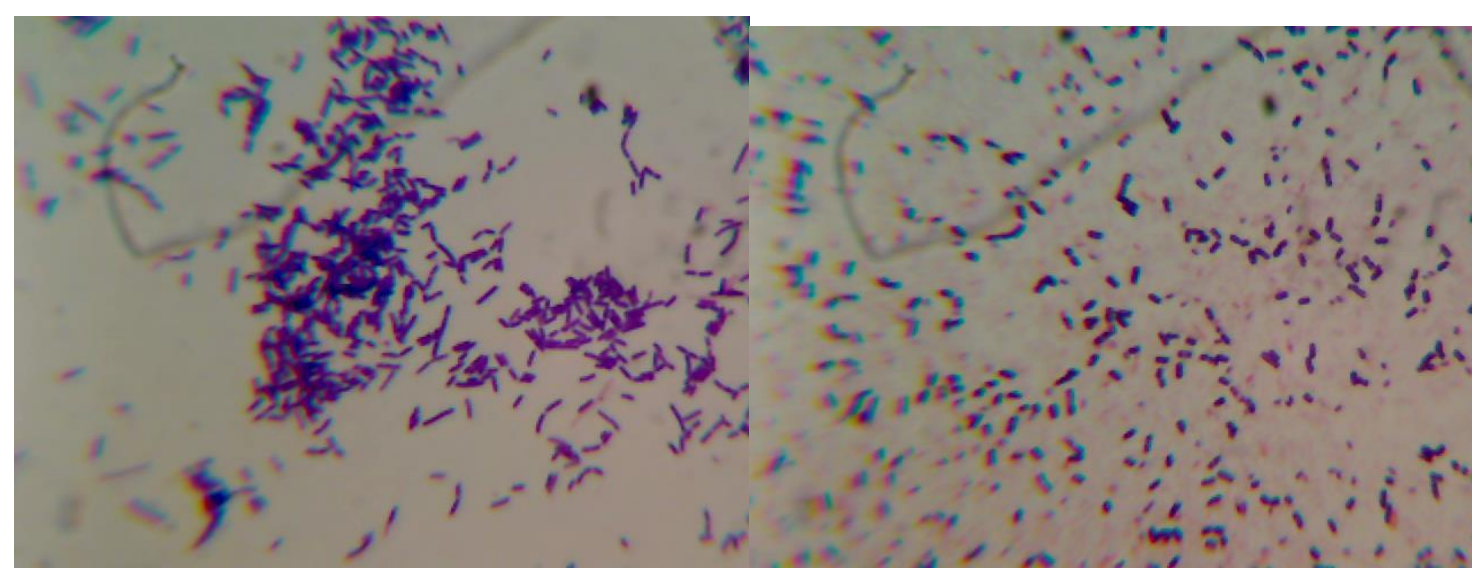

Gram +ve bacilli \& Gram +vecocobacilli isolated from milk sample in Kanombe sector

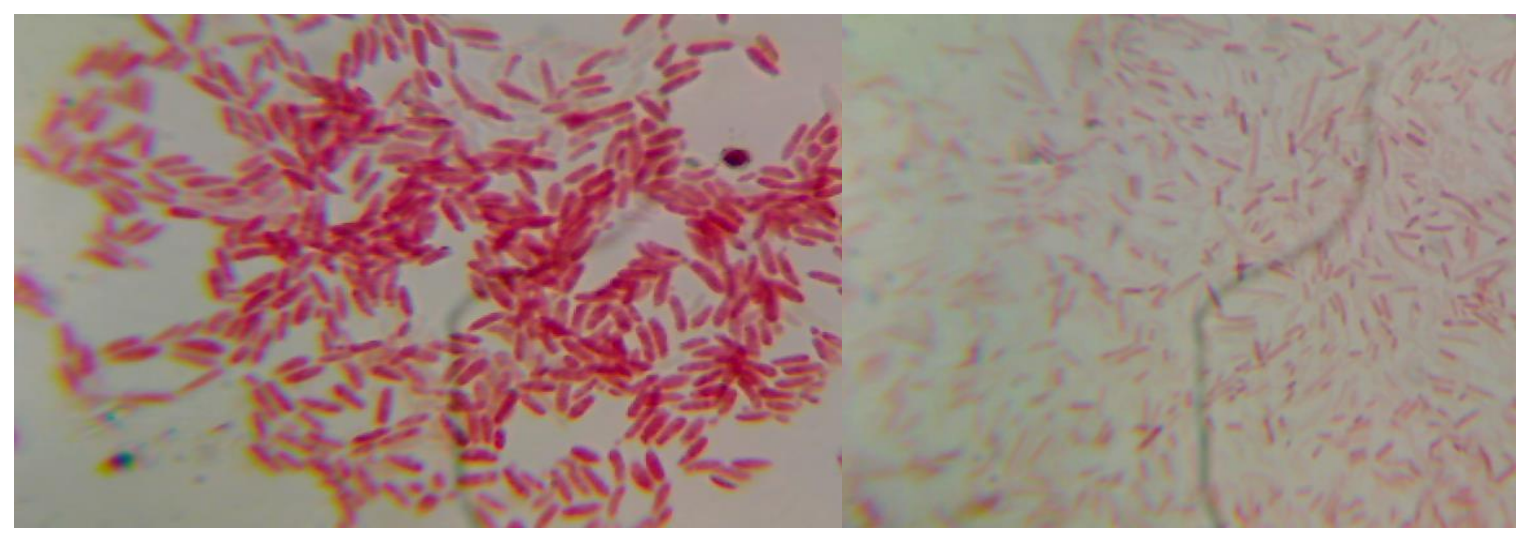

Gram -ve bacilli isolated from milk sample in Kicukiro sector 

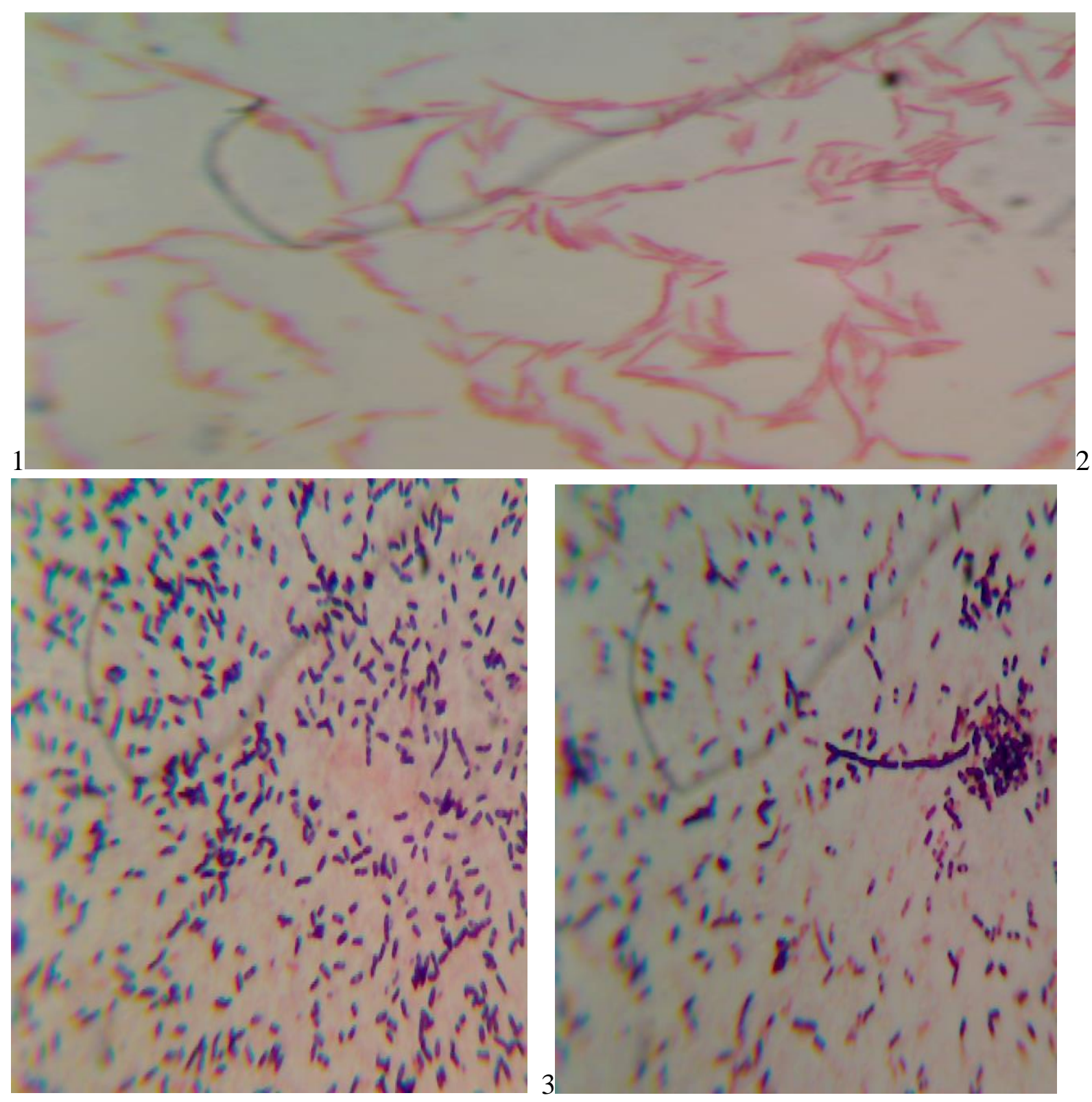

Gram -ve bacilli (1), Gram +ve coccobacilli (2) and Gram +ve\& -ve bacilli \& Gram + streptobacilli in macconkey gar (1) and nutrient agar (2\&3) respectively isolated from milk samples in Kigarama sector. 


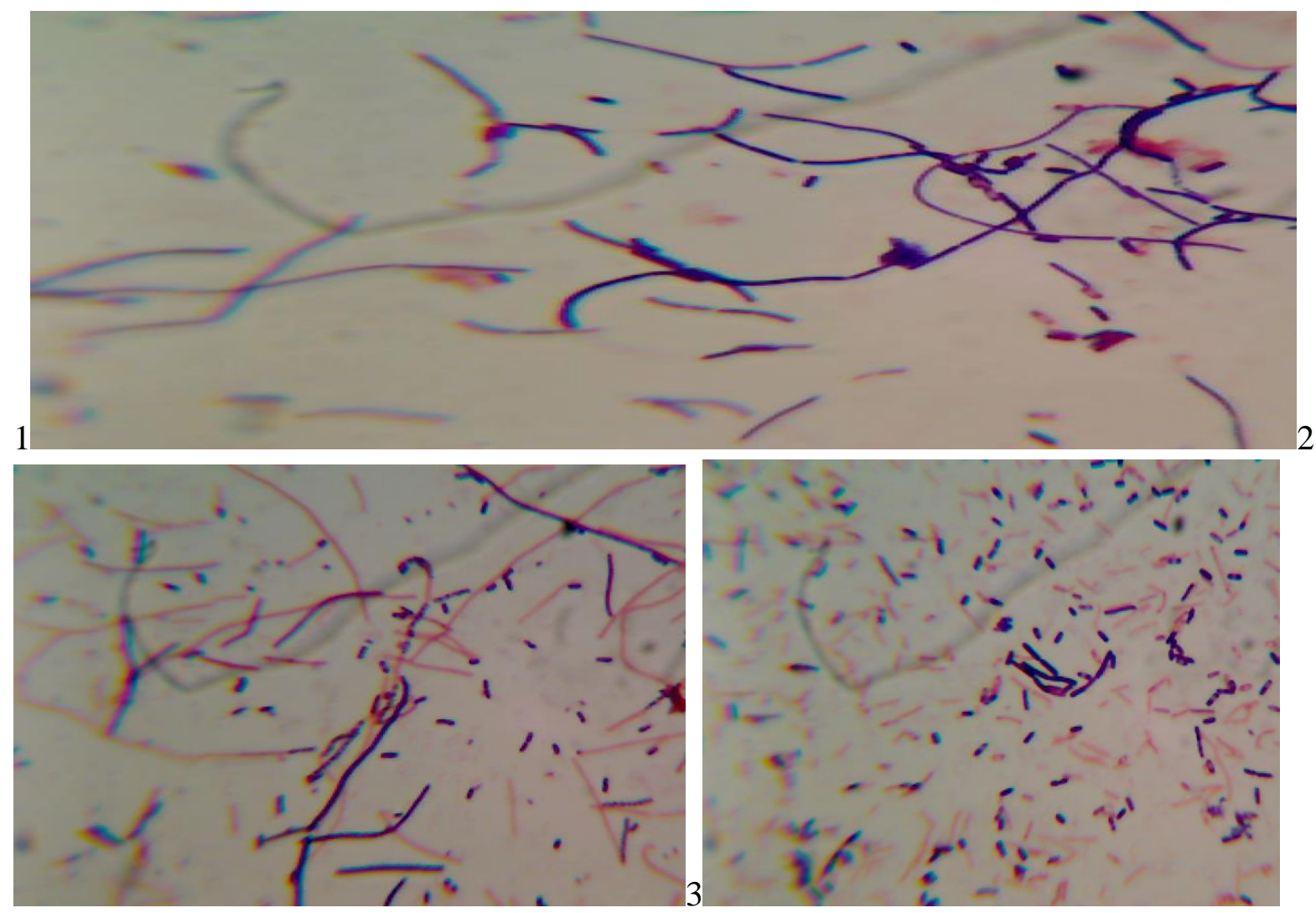

Gram +ve/-ve bacilli \&filaments(2), and Gram +ve bacilli \&coccobacilli, Gram -ve bacilli (3) isolated from milk sample in Masaka sector
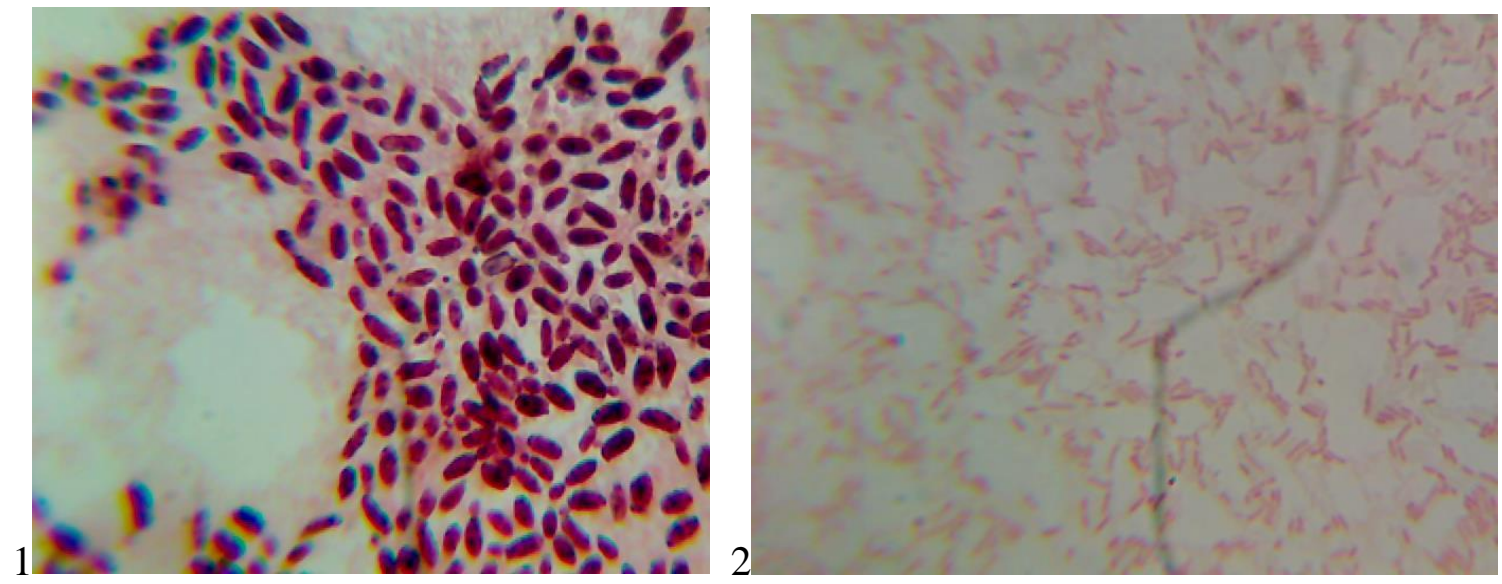

Gram -vecoccobacilli(1) \& bacilli (2) isolated from milk sample in Niboye sector 

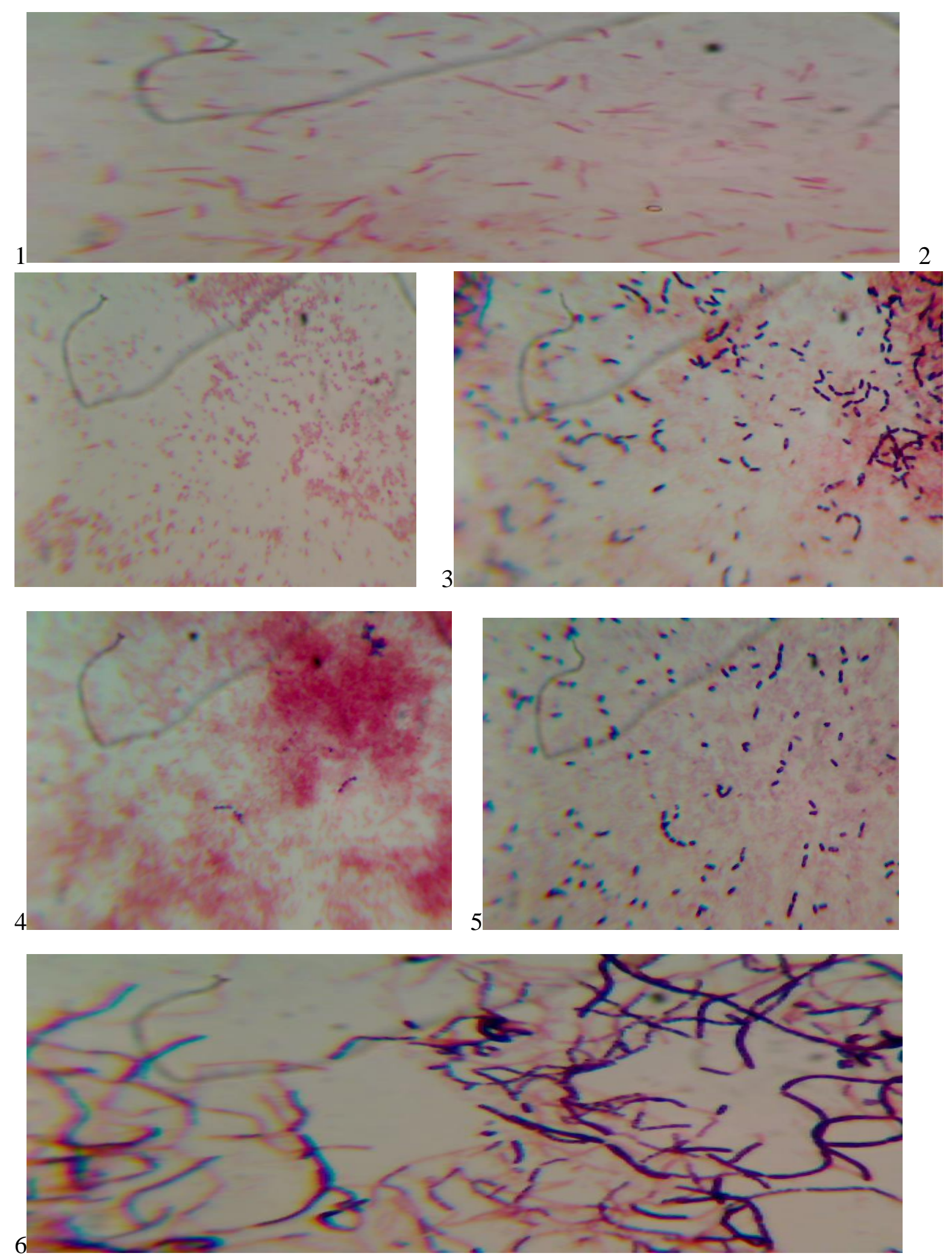

Gram -ve bacilli (1), Gram -ve cocci (2), Gram +veroda/bacilli (3), Gram +ve streptococcus (4), Gram + rod \&sreptobacilli (5), Gram +ve\& -ve filaments (6) isolated from milk sample in Nyarugunga sector 


\subsubsection{Biochemical tests}

Biochemical tests; catalase and coagulase were done after gram staining in order to identify some bacteria.

Table 3.4. shows the results biochemical tests (catalase and coagulase) done on the milk samples.

\begin{tabular}{|l|l|l|l|l|l|l|l|}
\hline Sectors & $\begin{array}{l}\text { No of } \\
\text { samples } \\
\text { analysed }\end{array}$ & $\begin{array}{l}\text { No of } \\
\text { samples } \\
\text { +ve for } \\
\text { catalase }\end{array}$ & $\begin{array}{l}\text { \% +ve } \\
\text { for } \\
\text { catalase }\end{array}$ & $\begin{array}{l}\text { No of } \\
\text { samples } \\
\text {-ve for } \\
\text { catalase }\end{array}$ & $\begin{array}{l}\text { \% -ve } \\
\text { for } \\
\text { catalase }\end{array}$ & $\begin{array}{l}\text { No of } \\
\text { samples } \\
\text { +ve for } \\
\text { coagulase }\end{array}$ & $\begin{array}{l}\text { \% +ve } \\
\text { for } \\
\text { coagulase }\end{array}$ \\
\hline Gahanga & 5 & 2 & $40 \%$ & 3 & $60 \%$ & 0 & $0 \%$ \\
\hline Gatenga & 5 & 4 & $80 \%$ & 1 & $20 \&$ & 0 & $0 \%$ \\
\hline Gikondo & 5 & 4 & $80 \%$ & 1 & $20 \&$ & 0 & $0 \%$ \\
\hline Kagarama & $\mathbf{2}$ & $\mathbf{1}$ & $\mathbf{2 0 \&}$ & $\mathbf{1}$ & $20 \&$ & $\mathbf{0}$ & $\mathbf{0 \%}$ \\
\hline Kanombe & 5 & 4 & $80 \%$ & 1 & $20 \&$ & 0 & $0 \%$ \\
\hline Kicukiro & 5 & 5 & $100 \%$ & 0 & $0 \%$ & 0 & $0 \%$ \\
\hline Kigarama & 5 & 2 & $40 \%$ & 3 & $60 \%$ & 0 & $0 \%$ \\
\hline Masaka & 5 & 3 & $60 \%$ & 2 & $40 \%$ & 0 & $0 \%$ \\
\hline Niboye & 5 & 3 & $60 \%$ & 2 & $40 \%$ & 0 & $0 \%$ \\
\hline Nyarugunga & 5 & 4 & $80 \%$ & 1 & $20 \&$ & 0 & $0 \%$ \\
\hline TOTAL & $\mathbf{4 7}$ & 32 & $68.1 \%$ & 15 & $31.9 \%$ & 0 & $0 \%$ \\
\hline
\end{tabular}

Table 3.4 shows the result of biochemical tests done on the samples; $68.1 \%$ of the samples were positive for catalase, $31.9 \%$ negative for catalase and none was positive for coagulase and it indicates that the milk samples are free from staphylococcus aureus contamination as no sample was positive for coagulase taste.

\section{Discussion}

The overall microbial quality of the milk supplied by milk sellers in kicukiro district can be said to be within Grade I to Grade III. $17.02 \%$ fell within Grade I, 23.40\% fell within Grade II, 19.14 
$\%$ fell within Grade III making a total of 59.56\% that fell within Grade I - Grade III $(<200,000 \leq$ $2,000,000 \mathrm{cfu} / \mathrm{ml})$ and $40.42 \%$ of the milk samples were not within the acceptable limit of total count quality as per East African Standards (EAS) and Common Market for Eastern and Southern Africa (COMESA) milk grading standard of 2,000,000 (2.0x10 $)$ CFU/ML i.e. Grade III.(Table 3.1). Most of the milk sellers interviewed said that they wash all they used during fermentation and this could be why there is reduction in the percentage of milk that is greater than 2,000,000.

The presence of fungi and other non-lactobacilli in most milk sample showed that the level of hygiene employed by the milk sellers is low. (Figure 3.1).

Also, from the questionnaire used to collect the milk sample of kicukiro district,26(55.3\%) out of 47 samples collected ferment their milk locally (Ikivuguto) and had nothing in place for sterilization of their equipment and cans, 21(44.7\%) buy fermented milk from industries. Only $8(17.02 \%)$ out of 47 had training on milk processing and contamination, 39(82.98\%) out of 47 had no training on milk processing and contamination

Those who sell fermented milk from industries are 21 while 26 sellers ferment at home. Out of 21 that buy fermented milk from industry, 11(52.4\%) had cfu/ml <2,000,000 and 10(47.6\%) had $\mathrm{cfu} / \mathrm{ml}>2,000,000$. Out of the 26 that ferment at home, 17(65.4\%) had cfu/ml <2,000,000 and $9(4.6 \%) \mathrm{had} \mathrm{cfu} / \mathrm{ml}>2,000,000$. A clear notice in these figures is that both have greater number $<2,000,000$ especially the home fermented sellers.(Table 3.2). A common notice in most of the restaurant is the presence of flies and this indicates poor hygiene and dirty environment, and this could imply that even the industrial fermented milk gets contaminated during handling as well.

In a similar research done by Megan M.D. et al, 2015 on "Microbiological Analysis of Raw Milk in Rwanda'" showed that less than $13 \%$ of the samples from kiosks where milk is sold directly to consumers meets the safe level of TBC per target standard while $94 \%$ of samples from the transporter segment has less than 2,000,000 cfu//ml and fell within COMESA grade III. The increase of TBC observed along the value chain may be due to several factors, including contamination, storage and transport in uncleaned cans and lack of controlled temperature along transportation. (Megan et al, 2015) 
All the milk sellers in Kicukiro district, Kigali Rwanda where the milk samples were collected had no cows and so could not know exactly the quality of the milk they buy from the suppliers. Also, the time of transporting the samples to the different milk sellers is a factor that could reduce the milk quality if the temperature is not maintained.

It is also good that no samples tested positive for coagulase test and this implies that all the samples are free of Staphilococcus aureus but the presence of fungi is some samples is worrisome as fungi is can cause serious infection to the immunosuppressed individuals.(Table 3.4).

A research done by Kevin (2012) in Kenya also shows that $78 \%$ of the milk samples from Limuru were of acceptable Total count as per the Kenya Bureau of Standards guidelines of $\leq 2,000,000$ cfu/ml. (Kevin. K. K. 2012).

\section{Conclusion}

The apparent overall good quality of the milk in the district shows the willingness of majority of the milk sellers to deliver milk with good quality to the consumers. In total, $59.56 \%$ fell within Grade I - Grade III $(<200,000 \leq 2,000,000 \mathrm{cfu} / \mathrm{ml})$ and $40.42 \%$ of the milk samples were not within the acceptable limit of total count quality as per East African Standards (EAS) and Common Market for Eastern and Southern Africa (COMESA) milk grading standard of 2,000,000 (2.0x10 $\left.{ }^{6}\right)$ CFU/ML i.e. Grade III.(Table 3.1). 68.1\% of the samples were positive for catalase, $31.9 \%$ negative for catalase and none was positive for coagulase indicating that the milk in the district is free from Staphylococcus aureus.(Table 3.4). There is possibility that if the milk sellers are trained on milk hygiene, the district as a whole will be delivering good quality milk within the standards of Common Market for Eastern and Southern Africa (COMESA) and East African Standards (EAS). The poor hygiene within the restaurants shows that most milk sellers do not really understand the effect of poor hygiene to the milk they sell. This research also has determined that Masaka sector has that highest percentage of milk samples with good quality that fell within Grade I. (Table 3.1). 


\section{Declarations}

\section{Consent for publication}

Authors have approved the publication of this paper.

\section{Availability of data and material}

The datasets used and/or analyzed during the current study are available from the corresponding author.

\section{Conflict of interests}

The authors declare no conflicts of interests as far as this publication is concerned.

\section{Ethical approval}

This research was conducted after the approval of Mount Kenya University and the milk sellers in sectors of Kicukiro district. The consents of the milk sellers were given through questionnaires.

\section{Authors' Contributions}

OGU came up with idea, collected data, conducted lab experiments, and drafted the proposal and manuscript. JBN helped in analysis of results, read and revised the manuscript for publication.

\section{Funding}

This study did not receive a special grant to declare here, However the laboratory experiments were supported by Mount Kenya University, Medical Laboratory Sciences department. Authors bought some consumables. The funder was not involved in the manuscript writing, editing, approval, or decision to publish this paper.

\section{Acknowledgements}

Authors are grateful Mount Kenya University to provide some laboratory facilities where the work was conducted experimentally. Special thanks to Zacchaeus Thiauri, a lab technologist in microbiology unit for his support during this work.

\section{References}

1. Bramley, A.J. and C.H. McKinnon. 1990. The microbiology of raw milk. pp. 163-208. In Dairy Microbiology, Vol. 1. Robinson, R.K. (ed.) Elsevir Science Publishers, London. 
2. Doyle, Megan \& Garcia, Sara \&Bahati, Emmanuel \&Karamuzi, Dennis \&Cullor, James \& Nandi, Somen. (2015). Microbiological analysis of raw milk in Rwanda. African Journal of Food Science and Technology. 6. 141-143. 10.14303/ajfst.2015.053.

3. Gonzalez, R.N., D.E. Jasper, R.B. Busnell, and T.B. Farber. 1986. Relationship between mastitis pathogen numbers in bulk tank milk and bovine udder infections. J. Amer. Vet. Med. Assoc.189:442.

4. Kevin. K. K. (2012). assessment of milk quality and the potential of a quality based payment system in small holder farms in limuru and eldoret, Kenya. Retrieved from http://erepository.uonbi.ac.ke/bitstream/handle/11295/13805/Kabui\%2C\%20KK_Assess ment\%20Of\%20Milk\%20Quality\%20And\%20The\%20Potential\%20Of\%20A\%20Qualit y\%20Based\%20Payment\%20System\%20In\%20Small\%20Holder\%20Farms\%20In\%20L imuru $\% 20$ And $\% 20$ Eldoret $\% 2 \mathrm{C} \% 20 \% 20$ Kenya.pdf?sequence $=4 \&$ isAllowed $=\mathrm{y}$ accessed on $20^{\text {th }}$ June 2018

5. Kurweil, R., and M. Busse. 1973. Total count and microflora of freshly drawn milk. Milchwissenschaft 28:427.

6. Murphy, S.C. K.J. Boor, Cornell University, Ithaca, NY. 2010. Sources and Causes of High Bacteria Counts in Raw Milk: An Abbreviated Review. Retrieved from http://articles.extension.org/pages/11811/sources-and-causes-of-high-bacteria-counts-inraw-milk:-an-abbreviated-review. On $27^{\text {th }}$ may 2018.

7. Tolle, A. 1980. The microflora of the udder. p. 4. In Factors Influencing the Bacteriological Quality of Raw Milk. International Dairy Federation Bulletin, Document 120.

8. Zehner, M.M., R.J. Farnsworth, R.D. Appleman, K. Larntz, and J.A. Springer. 1986. Growth of environmental mastitis pathogens in various bedding materials. J. Dairy Sci.69:1932. 